\title{
SUBVERSÕES PERVERSAS DA ESCRITA: ESPAÇO E CORPO, TESTEMUNHOS EM GONÇALO M. TAVARES
}

Fabio Fadul Moura ${ }^{1}$

Resumo: O presente trabalho analisa as representações do espaço, do corpo e dos testemunhos no livro Uma menina está perdida no seu século à procura do pai (2015), do autor português contemporâneo Gonçalo M. Tavares. Toma-se como recorte a presença da personagem Moebius e dos elementos que o circundam. Acredita-se que Gonçalo M. Tavares utiliza essa personagem como matriz para uma avaliação dos instrumentos da historiografia e das formas de construção do passado por essa ciência. Dessa forma, ele põe em xeque a imagem da escrita acerca do Holocausto, determinando seus limites e como o teor testemunhal (SELIGMANN-SILVA, 2003) responde a esse procedimento.

Palavras-chave: Literatura Comparada, História, Escrita, Testemunhos, Gonçalo M. Tavares.

\section{THE WRITING PERVERSE SUBVERSION: SPACE AND BODY, TESTIMONIES IN GONÇALO M. TAVARES}

\begin{abstract}
This paper analyzes the representation of the space, the body and the testimonies in the book Uma menina está perdida no seu século à procura do pai (2015) by the Portuguese contemporary author Gonçalo M. Tavares. The study revolves around the Moebius characters and the elements that are adjacent to him. It is believed that the author uses this character as model to an evaluation of the historiography and the ways of construction of a past by this science. Therefore, Tavares inquests the writing image around the Holocaust, determining its limits and how the testimonial aspect (SELIGMANN-SILVA, 2003) responds to this process.
\end{abstract}

Keywords: Comparative Literature, History, Writing, Testimonies, Gonçalo M. Tavares.

[...] Aqui está, ó rei, diz Theuth, o saber que proporcionará aos egípcios mais saber, mais ciência e mais memória (mnemonikoterous); da ciência (sophias) e da memória (mnemes) o remédio (pharmakon) foi encontrado. [...]

Platão

[...] Obviamente, esse arquivamento do testemunho é induzido e imposto pelo próprio acontecimento, pela estrutura do acontecimento. Um acontecimento não é um fato. A vontade genocidiária é, por excelência, a que anula, no cerne mesmo do acontecimento, a facticidade do fato. Portanto, é a que obriga, no mais alto grau, a vítima a fornecer a prova. [...]

Marc Nichanian

\section{A Literatura lê as ferramentas da História}

\footnotetext{
${ }^{1}$ Doutorando do Programa de Pós-graduação em Teoria e História Literária da Universidade Estadual de Campinas (UNICAMP), com bolsa de estudos de doutorado concedida pela Fundação de Amparo à Pesquisa do Estado de São Paulo (FAPESP). Pesquisador do grupo Relações de gênero, poder e violência em literaturas de língua portuguesa da Universidade Federal do Amazonas (UFAM).
} 
As epígrafes selecionadas para este texto são tomadas como ponto de partida e fios que se entrelaçam, conduzindo o caminho ao problema do testemunho e ao das formas de arquivamento. No mito de Platão, encontra-se uma fé na existência de um saber que permitirá mais memória e mais ciência aos egípcios. Esse saber traz uma hupomnèsis, uma memória que serve de apoio, de prótese. Com certa ambivalência, a palavra phamakon carrega a ideia de veneno conjugada à de remédio. Isso quer dizer que o operador do pharmakon, em um duplo movimento, pode ser curado ou, ainda, suspendendo a fé supracitada, intoxicado no exercício de sua perícia. Na argumentação de Nichanian, o arquivamento é compelido pelo acontecimento no plano histórico, porém, o processo de arquivamento encontra um impasse em sua execução, posto que o fato, que portaria a ideia de validade e existência, é obliterado pelo exercício do poder do genocida, isto é, pela aniquilação do grupo e da memória do mesmo grupo em único golpe. O memoricídio, nesse sentido, obscurece também a possibilidade de arquivamento que garantiria o lugar no discurso histórico. E a vítima é ironicamente levada a romper o paradigma positivista e oferecer-se enquanto material necessário como prova, a fim de ser de posta sob avaliação de outrem. Considerando as intervenções de Nichanian, o pharmakon ganharia um novo limite, pois não poderia haver prótese de algo que sequer possui facticidade e existência. Eis o problema para as testemunhas das catástrofes do século XX, tempo calcado na ideia jurídica da prova; por desdobramento, visualiza-se o norte do que neste texto se apresenta e se deseja discutir.

Respeitando o salto temporal entre o mundo grego antigo e essa era das catástrofes históricas (SELIGMANN-SILVA, 2008), cabe ter em mente que as tópicas do testemunho e do arquivamento encontram diversas representações, como pode ser visto, a título de exemplo, em Akira Kurosawa, com o filme Rashomon (1950), e Maurice Blanchot, com o texto L'instant de ma mort (de primeira publicação em francês em 1994). Diante de uma série de autores que versam sobre o impasse e sobre a conjugação dessas temáticas, selecionouse a figura de Gonçalo M. Tavares, escritor português contemporâneo, o qual, a partir da Tetralogia O Reino, encetou uma discussão, no campo da literatura, acerca das configurações do arquivo enquanto suporte da memória e do testemunho. Em Uma menina está perdida no seu século à procura do pai (2015), romance posterior à Tetralogia, encontram-se duas personagens que percorrem uma Berlim antiga: Hanna e Marius conhecem diversas 
personagens que, ao modo literário, ensaiam problemas da ciência historiográfica. Fried Stamm cola cartazes nas ruas para influenciar uma revolução, tomando-os como um arquivo que resiste e sobrevive, à margem dos meios oficiais " [...] como se a degradação do cartaz aumentasse a intensidade daquilo tudo; estão quase a desaparecer, mas não se calam. [...] (TAVARES, 2015, p. 35). Mais à frente, diante da carência de memória, fica evidente a vontade de Fried: “[...] queremos que as pessoas tenham boa memória, vejam pormenores, ganhem certa raiva que deve ser contida, controlada, concentrada, para mais tarde sair com mais força [...]”. E encerra, em possível diálogo com Didi-Huberman em Images malgré tout (2003): “[...] Tudo começa nestas imagens, nas fotografias. É a nossa introdução [...]" (TAVARES, 2015, p. 37). Também de maneira reflexiva e crítica, encontra-se no discurso de Vitrius a febre historiográfica e o mito do progresso: “[...] Trata-se de manter uma direção. Uma direção individual. E só por isso resistimos. E por isso estou aqui. [...] (TAVARES, 2015, p. 110). Cabe a ele continuar a contagem linear dos números - técnica ensinada a gerações na família - para identificar com precisão o evento histórico. Conforme esse ensinamento, ele seria capaz de saber, em idas e vindas, com base em uma única data, qualquer fato que tenha sido registrado nos documentos da família. Tanto no primeiro caso como no segundo, há formas do pharkamon de Platão: remédio, para Fried Stamm; veneno, para Vitrius. Explicita-se, entretanto, que à proposta do romance de Gonçalo M. Tavares não cabe uma interpretação unilateral em que as formas do pharmakon entram em choque. Pelo contrário, na esteira de Paul Ricœur, em $A$ história, a memória e o esquecimento (2007), visualiza-se que as trajetórias das personagens encenam alguns dos caminhos traçados pelo filósofo no seu esclarecimento sobre o percurso da memória declarativa até a fase documental. Não cabe aqui estabelecer uma relação direta entre as categorias de Ricœur e as personagens do romance. Entretanto, é com base no problema do arquivamento da memória e do testemunho que serão analisadas as atitudes de uma personagem: o judeu Moebius. Atentando a tal imagem como orientação, este texto procura pontuar as representações do corpo e do espaço como modalidades para o arquivamento. Com elas, a personagem do romance selecionado expõe a problemática dos testemunhos.

\section{2 “Um Kafka português": breve comentário sobre Na colônia penal}


Antes de adentrar o romance de Gonçalo M. Tavares, cabe esclarecer um título que a ele foi conferido pela escritora francesa Elisabeth Barillé na Le Figaro Magazine. O romance que a ele rendeu o epíteto de "Um Kafka português" foi Jerusalém (2004), porém, tal estética kafkiana parece ultrapassar o primeiro livro da Tetralogia e alcançar outros de sua obra. O ar sombrio, o desconforto e a inquietação despertada pelos textos de Franz Kafka ambientam as narrativas de Gonçalo M. Tavares, de sorte que ele opere um trânsito de formas e temas peculiares. A imagem de Moebius é uma delas, que recobra a gravidade das costas dos condenados de Na colônia penal.

Publicado pela primeira vez em 1919, encontra-se em destaque a figura de um oficial, que é o último adepto da forma de aplicação da justiça do antigo comandante. Ele conhece os detalhes da operação de uma máquina que tem status de penalidade máxima diante de um delito. Com ela, será inscrita nas costas do condenado a sentença que o leva, ao fim do processo, à morte. Durante o enredo, o que se verifica é que a perícia no uso da máquina se dá a partir da repetição, como pode ser notado pela minúcia na descrição de cada ferramenta. Segundo o oficial que a opera, ela um dia foi aclamada pela comunidade, que assistia à aplicação daquela forma de justiça. Isso quer dizer que texto de Kafka coloca na ordem do dia o antigo estatuto jurídico daquela comunidade e, consequentemente, em um plano mais amplo, como os membros da mesma coletividade foram coparticipantes mecânicos da aplicação da pena, isto é, engrenagens que foram e continuam sendo mobilizadas para a atualização do próprio estatuto. Ao condenado, por exemplo, não diz respeito o conhecimento da sentença. Aos olhos do explorador e do leitor - que se coloca igualmente como estrangeiro àquele contexto -, é descortinada a alegoria dos que contribuem com a era da tecnização da barbárie - desde antes dela - e fomentam o mecanismo jurídico que os esmaga e os sentencia à morte.

Se for permitido ler a ficção por uma chave teórica do testemunho, poderá ser extraída dela incialmente como primeira testemunha o oficial, na condição irônica de terstis: aquele que presenciou diversas aplicações da pena como um terceiro e que, agora, avoca para si a possibilidade de propagar pela linguagem e pela ação a presença da máquina como extensão da ordem do antigo comandante. $\mathrm{O}$ mesmo oficial perfaz um caminho discursivo com finalidade de convencer o explorador a aderir à sua vontade. Em contrapartida à proposta, o explorador incorre em uma objeção. A negativa aponta para o sujeito que avalia o sistema por ele testemunhado (com base na ação e no discurso do oficial-testemunha). 
Dizendo de outro modo: o explorador torna-se a nova testemunha do dinamismo da colônia penal e age diferentemente do que se espera pela lei, rompendo o modelo ético conhecido. A introdução do novo preceito ético afeta o oficial, que age de maneira inesperada: liberta o condenado e aplica sobre si a nova e última punição. Nesse momento, a presença do explorador que testemunha e age sobre a realidade testemunhada altera a ordem das ações, revelando ambiguidades no interior do sistema: aquele que era carrasco se torna vítima, tendo seu lugar de ação subvertido; a vítima, por seu turno, regozija-se com a execução do antigo carrasco, experimentando a posição de sujeito operador da máquina, mesmo que parcialmente. Em um segundo movimento, o oficial, que era a única testemunha, cede esse lugar aos outros três personagens (explorador, prisioneiro e soldado), que presenciam a última imputação da forma jurídica.

Segundo Ricœur, “[...] [a] especificidade do testemunho consiste no fato de que a asserção da realidade é inseparável do seu acoplamento com a autodesignação do sujeito que testemunha. Desse acoplamento procede a fórmula típica do testemunho: eu estava lá [...]" (2007, p. 172), configurada por Kafka no momento em que atesta a existência dos julgamentos - dos fatos passados - que se deslocam para o agora, junto ao oficial que faz sua narração no local do julgamento. Ele mesmo retoma a todo momento as lembranças de quem presenciou as execuções. $O$ discurso de persuasão do oficial e a narração desenvolvida por ele garantem o compromisso da história pessoal com as demais histórias a ela enredadas. Ainda na esteira filosófica, encontra-se no testemunho uma confiabilidade presumida (RICCEUR, 2007), isto é, a constatação da realidade factual do acontecimento relatado é associada à confiabilidade por parte dos receptores. No caso de Kafka, o explorador não desacreditou nem desautorizou o testemunho do oficial. A atitude de objeção do explorador ratifica a credibilidade conferida ao testemunho que se deu e se reitera pela ação e pela linguagem. Se “[a] autenticação do testemunho só estará então completa após a resposta em eco daquele que recebe o testemunho e o aceita [...]" (RICCEUR, 2007, p. 173), pode-se dizer que ele chancela o testemunho do oficial pela recusa imperiosa de adesão a todo o sistema da colônia penal.

Além da relação de confiança e credibilidade em que se enlaçam explorador e oficial, a qual também pode ser percebida em Marius ao ouvir a história de Moebius, essa pequena incursão se fez necessária pela imagem da escrita que aparece nas costas das vítimas da máquina e que também aparecerá na figura do judeu em Gonçalo M. Tavares. Ambos os 
textos trazem a escrita como suporte da memória. Em Kafka, o corpo sobre o qual se escreve precisa ser lido pela coletividade. Sendo assim, pelo testemunho do oficial, nota-se que não havia gratuidade na aplicação do código jurídico em público. A prática da escrita não se dissocia da prática da leitura, também encarada como meio de recordação. Em uma época em que todos presenciavam a aplicação da pena, a plateia podia ler a sentença cunhada nas costas dos condenados, tal como foi procedido pelo explorador com a morte do oficial. Assim, no espaço dessa cultura, a escrita, enquanto bupomnèsis, está a serviço da lei. Já em Gonçalo M. Tavares, Moebius conta que a origem de suas tatuagens está conectada a episódios que ocorreram anos antes: os assassinatos em série de homens judeus, sobre os quais se havia marcado um número pela extensão das costas. Cada número correspondia a um corpo, de modo que totalizavam doze vítimas. Pela declaração de Moebius, tem-se acesso a uma informação sobre a época em xeque:

[...] dado o ambiente da época (Moebius utilizou nessa altura a extraordinária expressão dado o oxigênio da época), não era por completo surpreendente, podendo encontrar-se mais de dez razões intelectualmente compreensiveis, disse o próprio Moebius, para alguém querer nos matar [...]. (TAVARES, 2015, p. 136)

O fragmento é composto por duas vozes que se entrecruzam. Marius, na condição de narrador do capítulo, demarca as inflexões de Moebius, das quais se extrai a prerrogativa do testemunho. Retomando Ricœur, a autodesignação no testemunho "[...] faz aflorar a opacidade inextrincável de uma história pessoal que foi ela própria "enredada em histórias"' (2007, p. 173). Diante de uma história que seria isolada, no romance é encontrado um motivo para cerzir a memória individual à coletiva, permitindo ao leitor compreender que o enredo se passa quinze anos após a perseguição dos judeus na Alemanha, como é apontado por Moebius no decorrer de sua explicação. Sabendo, ainda, que a lei está correlacionada aos desvios à norma, a existência daquela está atrelada ao crime enquanto instituição. Logo, tanto o episódio de Kafka quanto o de Gonçalo M. Tavares guardam em comum a ideia do corpo como suporte para uma escrita a serviço de instituições de poder e violência, a fim de que essa memória seja assinada no corpo de forma direta. O corpo absorve o oxigênio da época, de modo que é afetado pela atmosfera criada pelas instituições de controle, as quais o sujeitam. Seja pela justiça na colônia penal, seja pelo crime no assassinato dos judeus, o ato 
de escrita que perfura o corpo individual para imprimi-lo com violência física alcança um plano de violência psíquica (também coletiva).

Não caberá aqui espaço para uma discussão sobre a violência psíquica e sua relação com o trauma individual e coletivo refletido na figura de Moebius. No entanto, é necessário se debruçar sobre as noções de escrita e de arquivo, uma vez que entre si elas estabelecem diálogo com a memória, muito embora apontem para direções diferentes. Eis o próximo passo deste trabalho.

\section{Potência de arquivamento, o arkheîon}

$\mathrm{Na}$ abertura de sua epistemologia da memória, Paul Ricœur alerta: a noção de inscrição possui um sentido que extrapola a escrita como fixação de expressões orais. Enquanto a primeira estaria inclinada à memória viva, a segunda voltar-se-ia à exteriorização dessa memória, o que quer dizer que toda escrita pressupõe um suporte no qual possa ser impressa. As palavras de Ricœur, nesse caso, alinham-se ao que depreende Jacques Derrida (2001) da ideia de arquivo, que igualmente é fundado na exterioridade que o distingue da memória. Desdobrando sobre o romance essa exterioridade cara a ambos os teóricos, acredita-se que Moebius, ao ser marcado com as tatuagens, obedece a uma lógica alegórica produtora de um arquivo da História. Para tanto, ele mobiliza as configurações de suporte físico e jússico. Explica-se: no decorrer do romance, Marius e Hanna buscam por um lugar onde possam estar durante certo tempo. O espaço encontrado é um hotel, cujos donos são Moebius e a esposa Raffaela. Moebius é aquele que detém da autoridade domiciliar, mas também em suas mãos está concentrada a capacidade hermenêutica de organizar, de ler a disposição das coisas e de atribuir significado ao interior daquele espaço. Desse modo, a trajetória dos protagonistas sugere o sentido da palavra arkheîon, pois, ao buscarem hospedagem nesse lugar, as personagens depositam-se sob o domicilio do arconte. Leia-se parte do episódio em que Marius conversa inicialmente com Raffaela:

- Os quartos não têm número? - perguntei.

- Só têm nome. O hotel é pequeno, é fácil chegar lá. É depois deste longo corredor. Encontra rapidamente o quarto.

Olhei de novo para a placa de madeira. Não havia qualquer dúvida. O que estava escrito na placa de madeira era AUSCHWITZ.

- Este é o nome do quarto?

- Sim - respondeu ela. 
$[\ldots]$

E afastou-se para eu poder ver atrás dela o mapa dos quartos. Todos tinham o nome de um campo de concentração: TREBLINKA, DACHAU, MAUTHAUSEN-GUSEN.

Marius pensou em várias coisas ao mesmo tempo. Teve o impulso de virar as costas de imediato e de tirar Hanna dali, mas não o fez.

- Porque fazem isso?

- Porque podemos - respondeu a senhora, secamente. - Somos judeus. (TAVARES, 2015, p. 52-53)

A noção de suportes de fixação da memória por via escrita e geográfica perpassa toda ambientação do hotel. Nas placas de madeira são cravados os nomes dos quartos; na parede da recepção, um mapa é pregado para a orientação dos hóspedes. Além disso, a extensão do corredor terrifica Marius, que se encontra perplexo devido à consciência do significado daqueles nomes. A narrativa joga com a transferência do pavor, originado por uma das catástrofes do século XX, sobre a geografia. A projeção espacial do mapa guia os hóspedes, portanto, a uma cartografia da catástrofe com base nos campos de concentração genocida. Conforme Derrida, “[n]ão há arquivo sem o espaço instituído de um lugar de impressão. Externo, diretamente no suporte, atual ou virtual" (2001, p. 8). Pelas impressões nos detalhes físicos, o hotel carrega uma combinação entre espaço e escrita, evidenciando formas de legibilidade que corroboram para a manutenção da memória da Shoah enquanto fábrica dos mortos. Ainda à luz de Derrida, depreende-se do espaço previamente construído por Moebius uma preparação de sua apresentação no romance. Toma-se, assim, as duas ordens designadas pelo conceito arkhê: a de comeģo e a de comando. Em outras palavras, a primeira ordem sinaliza o princípio da História, prevendo uma organização sistêmica em escala cronológica a partir de um momento originário. No romance, o evento demarcador da origem são os assassínios no tempo de Auschwitz. Gonçalo M. Tavares mescla ficção e fato histórico, ao passo que elabora uma personagem que planeja e ordena toda sua morada em função do que ela deve guardar, seguindo, ainda, um princípio nomológico relativo ao exercício de autoridade. A resposta de Raffaela à indagação de Marius sanciona a instituição que nasce a partir dos crimes contra os judeus, uma vez que aos arcontes cabe o estatuto de guardiões e intérpretes dos arquivos.

Da disposição dos elementos no corredor abstrai-se a intenção de Moebius. Para chegar ao quarto Auschwitz, é necessário passar em frente a outros dois, Buchenwald e Gross-Rosen. E todos guardam uma característica comum: “[...] os quartos tinham uma placa metálica, ligeiramente acima do olho de vigia, com o nome. [...]" (TAVARES, 2015, 
p. 54). Ocorre uma seleção de um hupomnema. Diferentemente do que é utilizado para a confecção dos chaveiros, as placas dos quartos são de outro material, mais resistente, duradouro. Além disso, são os quartos os possuidores dos olhos que vigiam, colocando os hóspedes na condição de observados, à medida que os transforma em objetos no interior do hotel. Não é necessário lembrar que os sistemas de controle, segundo Foucault (2004), também são distribuídos por meio de uma escala e que essa modalidade prevê o cuidado sobre uma massa informe, além de um trabalho primoroso que encara o detalhamento como possibilidade de exercer sobre o corpo uma coerção exaustiva. A atitude coercitiva aparece no corredor do hotel por meio do campo de associação entre a durabilidade do material escolhido e o ato de vigiar. Eles atuam como dispositivos atualizadores da memória genocidiária, os quais, simultaneamente, aplicam o medo. Marius tenta inutilmente cobrir a perversidade daquele sistema de memória encarnado no chaveiro no momento em que esconde o nome Auschwitz com os dedos. Entretanto, Gonçalo M. Tavares utiliza uma estratégia textual interessante para demonstrar que a memória da catástrofe se levanta como um fantasma: “AU............Z” (TAVARES, 2015, p. 54). As letras que a mão de Marius não consegue cobrir são visualizadas pelo recurso textual que promove a visibilidade ao leitor, de sorte que seja elaborada uma atmosfera fantasmal.

O pharmakon impossibilita que a memória seja apagada por completo. Ao mesmo tempo, ele impõe um obstáculo relativo sobre quem tenta abafá-lo. Por esse motivo, no episódio, Moebius é impactado pelo limite instituído pela escrita, ou, ainda, pelo rastro deixado pelo sistema. Novamente à guisa de Derrida, como instrumento do poder arcôntico, ela está a serviço do poder de consignação: esse poder se concentra nas ações de identificação de cada quarto ao respectivo nome; de unificação dos grupos semânticos reunidos de acordo com a simulação da lógica genocida; e de classificação de matrizes em que possa ser cunhada a memória na ordem de legibilidade (portas, chaveiros, mapas e todos os demais objetos nos quais se pode calcar uma caligrafia que remete ao pavor dos judeus no interior dos campos nazis).

Na continuidade do romance, Marius é convidado por Moebius para uma conversa no escritório:

[...] Moebius abriu uma gaveta e tirou de lá algo enrolado que depois foi desenrolando em cima da mesa. Era um mapa. A princípio não identifiquei nem sequer a geografia geral, mas rapidamente percebi ser a 
Europa, e depois, a pouco e pouco, os pequenos pontos assinalados e as palavras que os acompanhavam ficaram claros. Era um mapa onde estavam marcados os locais dos campos de concentração nazis.

- Estão aqui todos os Campos - disse Moebius.

- E agora - continuou ele - olhe, por favor, para a planta do hotel. E virou o tronco e o rosto para a planta do hotel que estava na afixada na parede do escritório e que era idêntica à que eu vira pela primeira vez, perplexo e assustado, no dia de chagada, atrás do balcão de recepção.

A planta do hotel era, mais milímetro, menos milímetro, uma cópia da estrutura geométrica formada pelos pontos que no mapa assinalavam os Campos. [...] Não havia qualquer referência à ordem alfabética, nem qualquer relação com o tamanho ou com o número de camas no seu interior - a relação era uma relação geográfica [...]. O hotel era reduzido, é certo, minúsculo, uma miniatura, mas era, em termos proporcionais, a cópia extacta da geografia dos campos de concentração.

- Foi feito de raiz - disse Moebius, falando do hotel - por um arquitecto nosso amigo, judeu.

- Veja - disse-me Moebius, enquanto num papel vegetal que colocara por cima do mapa assinalava os pontos onde estava cada Campo -, se unirmos com uma linha cada um destes pontos, onde se encontrava um Campo, obteremos uma forma geométrica. (TAVARES, 2015, p. 94)

Geografia, arquitetura, testemunho: os três campos são entrelaçados nas palavras de Moebius e por ele apresentados com base em documentos que garantiriam a veracidade de provas. Do mapa da Europa nasce um novo território, que surge simultaneamente para Marius como estranho e familiar. O Unheimlich freudiano parece ser experimentado pela personagem, que, aos poucos, compreende o problema que lhe está sendo exposto. Ele não reconhece em um primeiro momento o que está diante dos olhos, muito embora esteja mais próximo do que imagina. Ele precisará que Moebius sobreponha as folhas para ter consciência progressiva da totalidade, familiar, que o deixa perplexo. A forma geométrica de que Marius toma consciência no relato de Moebius diz respeito ao que é conhecido por ser impossível sustentar a recusa de sua existência -, todavia, é igualmente intraduzível e irrepresentável.

Encontra-se nessa exposição um apego à prova documental representada pelo mapa. Pautado no escalonamento excessivamente detalhista, o texto salienta esse campo discursivo guiado pelos locais: "geografia geral", "mais milímetro, menos milímetro", "estrutura geométrica" são algumas das expressões que denotam referências espaciais. Elas apontam para uma prévia investigação sobre o espaço e encontram apoio em uma linguagem própria à técnica científica, pressupondo o par localização-deslocamento no 
interior daquilo que ganha autonomia na ideia de uma "geografia dos campos de concentração". Esse horizonte geográfico singular é empregado como parâmetro que recai sobre a configuração arquitetônica do hotel, de sorte que o topográfico e o arquitetônico sejam entrecruzados com a base topo-nomológica do arconte. O resultado será a criação de uma nova forma geométrica, até então desconhecida pela humanidade e, devido a isso, inominada. O que seria lançado por essa ausência a um campo semântico esvaziado de sentido perfaz um caminho contrário no texto; ele é preenchido pelos rastros detectados por uma técnica, cujo objetivo é a definição de um novo espaço transnacional, tendo como objeto de pesquisa o próprio território europeu no período de guerra. O que chama a atenção no caso é que esse espaço é construído à revelia dos procedimentos formais insinuados pela "ordem alfabética". Abstrai-se, então, a ideia de que, no interior da lógica europeia erudita, estaria se tecendo outra lógica, a da barbárie.

Recuperando a proposta de Paul Ricœur, o arquivo será “[...] lugar físico que abriga o destino dessa espécie de rastro que cuidadosamente distinguimos do rastro cerebral e do rastro afetivo, a saber, o rastro documental. [...]" (2007, p. 177). Uma vez abrigado nesse lugar exterior, o rastro está assegurado pela possibilidade de consulta, de repetição, de reprodução e de reimpressão. Isso colocaria o arquivo na condição de salvador do testemunho arquivado. Porém, se o arquivo é ruptura com o testemunho, assumindo primeiro plano e visando aos rastros da própria atividade arquivadora para, assim, inaugurar o ato de fazer História, não é gratuita, nesse raciocínio, a criação de um espaço baseado na geografia estruturante da catástrofe. O hotel é a estrutura arquivante do conteúdo que nele será encerrado, isto é, da presença de um projeto genocida em larga escala (inicialmente ignorado). Nesse momento, o romance lança luz sobre a ironia que vem se desenvolvendo contra a ânsia positivista pela prova documental e sugere uma indagação: como seria possível exigir provas aos mortos? Em resposta a essa pergunta, em que está implícita a desconfiança do valor do testemunho, o projeto de Moebius e de seu amigo arquiteto, ambos judeus, brinda o negacionismo e historiografia positivista com o hotel. No decorrer de sua análise, Paul Ricœur pondera:

Esse gesto de separar, de reunir, de coletar é objeto de uma disciplina distinta, a arquivística, à qual a epistemologia da operação histórica deve a descrição dos traços por meio dos quais o arquivo promove a ruptura com o ouvir-dizer do testemunho oral. Naturalmente, se os escritos constituem a porção principal dos depósitos de arquivos, e 
se entre os escritos os testemunhos das pessoas do passado constituem o primeiro núcleo, todos os tipos de rastros possuem a vocação de ser arquivados. Nesse sentido, a noção de arquivo restitui ao gesto de escrever toda a amplitude que lhe confere o mito de Fedro. Pela mesma razão, toda defesa do arquivo permanecerá em suspenso, na medida em que não sabemos, e talvez não saibamos jamais, se a passagem do testemunho oral ao testemunho escrito, ao documento de arquivo, é, quanto a sua utilidade ou seus inconvenientes para a memória viva, remédio ou veneno - pharmakon... (2007, p. 178)

Compreende-se que a linha argumentativa nessa epistemologia surge como a mais adequada à atitude ácida das personagens do romance. Na composição de seu arquivo, Moebius ironiza a manipulação das etapas de trabalho da arquivística para produzir um grande arquivamento do gesto genocida. Diante da ruptura da relação entre a testemunha e o receptor, a declaração de Moebius e, consequentemente, de qualquer um que se lance de encontro às instituições de poder e violência, não terá a mesma sorte do explorador no texto de Kafka. Por não ser capaz de alterar o modelo ético do sistema, ele procura outra alternativa no interior do próprio dispositivo historicizante: a saída dele é se apoderar dessas ferramentas para subvertê-las. Ele julga a fé nos documentos escritos e desdobra o julgamento do paradigma do registro sobre outras formas de rastros. Insinua-se, assim, um segundo questionamento: se todos os tipos de rastros estão sujeitos ao gesto de arquivamento, como arquivar o testemunho dos mortos? Ou, ainda: como arquivar a morte se não há testemunhas nem outra forma que possa ser criptografada pelo arquivo? É necessário lembrar que o gesto genocida aniquila qualquer possibilidade de memória. Às gerações posteriores à aplicação da vontade genocidiária (NICHANIAN, 2012), resta apenas a crença de que a cultura exterminada nunca existiu. Desse modo, o romance acompanha as ressalvas de Ricœur, que recobra o mito platônico como quem lembra o leitor de que ele sabe dos segredos e dos limites do pharmakon.

\section{O corpo-tumba ou o corpo babélico dos mortos}

Explicadas a origem das tatuagens e do projeto arquitetônico do hotel - ambos subsumidos no genocídio -, pode-se alcançar a escrita das costas de Moebius com outro olhar. Aleida Assmann aponta que, para os antigos egípcios, “[...] tornou-se um topos fixo a noção de que a escrita permanece intocada pela ação destrutiva do tempo e de que ela representa um medium único para a imortalidade. [...]” (2011, p. 195). Discorrendo sobre 
Henrique $V$, de Shakespeare, Assmann continua: "[a] memória corporal de feridas e cicatrizes é mais confiável do que a memória mental. Embora esta se esfacele na velhice, o que é de se esperar, aquela nada terá perdido de sua força [...]" (2011, p. 265). A necessidade de mediação e de eternižação, no primeiro caso, prenunciava um caminho similar ao traçado por Ricœur na fase do arquivo (e do lugar social por ele ocupado), que corresponde ao valor que a escrita tem no mundo contemporâneo. Distinto da memória, o arquivo pode ser manipulado em seu suporte em diversos contextos, e sua materialidade garante a publicidade. Essa sobrevalorização da escrita a alçaria a um status superior ao da memória, de modo que toda lembrança considerada importante deveria ser registrada na intenção de materializá-la pela palavra, ou seja, havia uma fé em uma posse que concretizaria o propriamente virtual. Essa materialização garantiria a ultrapassagem por gerações. Portanto, o foco principal desse projeto de imortalização era uma transmissão errática capaz de romper o ritmo arrasador do tempo. No segundo caso, é superestimada a confiabilidade das impressões no corpo. As marcas de guerra teriam a propriedade de acionar lembranças que a memória mental naturalmente deixaria de reter. Explicita-se, ainda, que seria interessante pensar as marcas como indicadoras de duas impressões: a na pele e a do trauma. Com isso, a dor seria mais que um argumento físico exigido; mas o que psicologicamente jamais deveria arrefecer. Sendo assim, o traço comum entre os exemplos de Assmann é a persistência, isto é, a marca do que resiste e, em vista dessa obstinação, pode transcender o tempo.

$\mathrm{Na}$ segunda vez em que Marius é convidado para uma conversa no escritório, Moebius mostra as próprias costas. Elas estavam completamente riscadas, “[...] parecendo gatafunhos feitos por crianças. Como um muro vandalizado, as costas tinham a sua superfície totalmente preenchida por tinta" (2015, p. 135). Ocorre aqui a primeira apresentação de elementos metafóricos de eternização. A falta de clareza dos "gatafunhos" opõe-se à nitidez da "tinta". Diante dessas nuances do visível, relacionadas à marca do tempo sobre o corpo, um elemento central reúne-as e cristaliza-as no poder do suporte e da escrita. O "muro vandalizado" é a metáfora que carrega um genitivus subjectivus (ASSMANN, 2011), apontando para a possibilidade do local de memória como sujeito portador da recordação e de uma memória mais forte que a capacidade mnemônica dos homens. No caso do romance, sujeito e loci são o mesmo corpo. Moebius é o "muro humano" (TAVARES, 2015, p. 135), então, devido à transferência de valores espaciais para 
a personagem, ele resiste e conserva-se em único golpe. Assumindo que "[...] o espaço corporal é de imediato vinculado ao espaço do ambiente, fragmento da terra habitável, com suas trilhas mais ou menos praticáveis, seus obstáculos variadamente transponíveis [...]" (RICCEUR, 2007, p. 157), Moebius torna-se eixo de onde partem duas linhas de força colidentes com a primazia do arquivo documental: a primeira, que encaminha a interpretação para as gerações (de mortos); e a segunda, à fuga de sobreviventes que se deslocam para outros lugares do mundo.

Leia-se, à esteira desse primeiro vetor, mais um fragmento do romance:

As suas costas, como disse antes, a uma certa distância, pareciam um emaranhado de traços indefinidos com uma única função: ocultar a superfície da pele. O facto de, depois de me aproximar, aqueles traços que pareciam desenhos - se mostrarem como eram realmente - traços ordenados que constituíam, na maior parte dos casos, letras bem conhecidas - foi uma surpresa semelhante à que se tem quando, de entre um conjunto de rostos informes e desconhecidos numa multidão, subitamente, um rosto se destaca - e só aí percebemos que aquele rosto não é apenas um rosto já conhecido, mas sim o rosto do nosso pai. [...] (TAVARES, 2015, p. 135-136)

É necessário sublinhar que Moebius faz as primeiras tatuagens acometido por uma espécie de um "orgulho de raça" (TAVARES, 2015, p. 137) sobre o qual recai a tópica do sobrevivente do genocídio. No ocultamento da pele, Moebius e, concomitantemente, Marius são subsumidos, cada um a seu modo, em um grupo familiar, a fim de que o último acorde para a ideia da dor (no caso, a dor coletiva) como uma herança ironicamente inalienável. A aproximação, nesse passo, leva ao reconhecimento de um projeto de escritura metódico. O que está escrito nas costas de Moebius é a palavra “judeu”; não uma, mas diversas vezes (em pontos e línguas diferentes). Isso preenche toda a extensão das costas - recobrando o número marcado nas costas das vítimas dos assassinatos do livro e nos corpos das vítimas dos campos de concentração. O jogo de semelhanças é ampliado no momento em que a figura do pai é evidenciada. O texto sugere o impacto dramático da anagnorisis, agora desdobrado sobre a figura que desperta um afeto em uma descoberta particular: a coincidência entre o "pai" e a palavra impede que as gerações exterminadas em massa tenham as mortes ignoradas. Nesse sentido, a potência de eternização pelo espaço e pela escrita é acionada para que a morte não apenas recuse o esquecimento, mas também para que garanta a própria existência. 
Diante desse contexto, recorre-se à palavra de Hélène Piralian acerca da figura dos sobreviventes armênios, para se pensar como tais figuras podem ser utilizadas como luz a iluminar outros sobreviventes de catástrofes do século XX:

[...] ante toda esta muerte (muerte de ellos) y en cuanto sus herederos, los sobrevivientes hacen suyo el deber de permanecer no ya en el campo de la vida sino en el aún más fundamental de la existência y la necessidad, que va a forzarlos, si quieren retener a esos muertos al margen de la inexistencia, a no tener otro presente posible más que el tempo en que aquella muerte se produjo, suspendido y a la vez retomado indefinida e intemporalmente. (2000, p. 20)

Para ela, o problema das gerações de sobreviventes do genocídio armênio sobre as quais incide o negacionismo político não é diretamente o esquecimento, pois o fundamento deste último estaria pautado em uma memória possível. O problema é anterior e está relacionado à negação da existência do genocídio. Com essa argumentação, Piralian, apesar de falar de outro campo científico, está emparelhada ao pensamento de Marc Nichanian acerca da aniquilação do fato histórico na epígrafe a este trabalho. Antes de toda a morte, os herdeiros tomam como dever conservarem-se como aqueles que salvarão a morte no campo da vida. Dizendo de outro modo: há a vida, a morte e um terceiro valor cuja existência é esvaziada e lançada para o campo do não-ser, portanto, os sobreviventes têm por necessidade retirar os mortos desse terceiro não-espaço, o da inexistência. Para tanto, eles realizam um deslocamento dos mortos para a zona abismal da morte, a fim de que, após isso, seja a eles conferido o estatuto da morte. Apenas assim eles poderão existir através da morte - que agora será reconhecida. Diante do projeto genocida, ao sobrevivente não cabe ter outro presente possível além do tempo em que a morte ocorreu, logo, o "[...] acto de simbolización como deconstrucción de los montajes genocidas y al mismo tiempo (re)construcción de un espacio simbólico de vida [...]" (PIRALIAN, 2000, p. 21) pode ser associado ao projeto que inicia nas tatuagens e se estende à construção do hotel. Moebius mina as estruturas da lógica genocida para devolver a elas as próprias estratégias discursivas às avessas. Tratando-se de um tempo e de uma morte suspensos ou tomados de vez, é no campo da simbolização da escrita e do espaço que ele oferecerá a possibilidade de (re)escrever a partir da morte. O que está em evidência nesse caminho não é mais a estratégia de eternizaçãa, mas, antes dela, a de transmissão. Dar conhecimento da morte é necessário para que ela exista. Sendo transportado para o campo da existência, o 
projeto historiográfico de ordem positivista que visava dizimar a memória da catástrofe perde força. Ainda segundo Piralian,

[...] [d]ado que la aceptación de su muerte no correspondería a la de un muerto que ha estado vivo, sino que, como un segundo asesinato, aún más radical que el precedente, confirmaría su no existencia. Aceptarla sería participar en su borradura del orden de lo humano. Por eso, incapazes de enterrar a sus muertos, los sobrevivientes no pueden más que ofrecerse como tumbas para que se suspendan a la vez su muerte y su desaparición. Rechazar la muerte real se convierte, entonces, en la única manera de salvar la posibilidad misma de la Muerte. [...] (PIRALIAN, 2000, p. 32)

O triunfo de Moebius pelo caminho da simbolização é expresso: "Nem depois de morrer isto vai sair - disse Moebius, entre a ironia e uma qualquer convicção estranha desajustada" (TAVARES, 2015, p. 135). Com essa estratégia, tem para si a garantia de que não será possível apagar os rastros produzidos por ele e pelo projeto genocida, logo, tudo aquilo que está atrelado ao sistema será acoplado a e transmitido com essa memória da catástrofe (inclusive a morte dos que lhes eram próximos). As várias línguas em que foi escrita a palavra "judeu" denotam a refutação radical da morte. Infere-se da proposta de Piralian que, uma vez aceita a morte, ela ampliaria o campo de aplicação do projeto genocida, ao passo que o sujeito de adesão ao sistema colaboraria com a naturalização da barbárie. A transformação do corpo em tumba, em contrapartida, revela um vínculo peculiar que põe em diálogo as ideias de proximidade e de distância. Com as tatuagens, os mortos habitam outro campo simbólico, antes impossível. O que agora ganha dimensão de passado pode ser trazido ao campo discursivo do testemunho pela palavra, pelo corpo e pelo espaço no ato presente da enunciação da fórmula testemunhal Eu estava lá, operada, em segundo plano, por uma série de instrumentos subversivos.

Seleciona-se um fragmento em que Moebius se apropria da escrita para pervertê-la outra vez, mas agora de acordo com o segundo vetor anteriormente mencionado, devidamente entrelaçado ao primeiro:

Enfim, estava - lembro-me de pensar - perante um dicionário em todas as línguas do mundo, mas dicionário de um único vocábulo. Dicionário que era ainda, simultaneamente, um mapa anatómico e geográfico. É que, de facto, a obsessão pela localização e orientação dos diferentes pontos era ostensiva, mostrando que, anos antes de o casal ter feito o hotel, a fixação cartográfica já existia. Observando atentamente as 
coisas pude então reparar que poderíamos acompanhar a localização dos diferentes países no mapa, fazendo ali, na pele de Moebius, exatamente o mesmo trajeto da visão, tendo o nome de cada país sido ocupado pela palavra judeu escrita na língua falada nesse ponto do mundo. (TAVARES, 2015, p. 137-138)

A memória das cicatrizes perpassa a memória da tatuagem. Em ambos os casos, as marcas são impressas na pele a custo da dor. Os atos de perfuração da pele só divergem no sentido da intencionalidade. Enquanto o primeiro, mesmo que desejado, foi feito em um contexto de combate; o segundo foi previamente pensado e conscientemente recebido por meio de uma técnica cujo momento de aplicação não coincide com as práticas bélicas. A composição encontrada nas costas de Moebius resulta de um planejamento que prevê a transmissão do trauma como resultado. O corpo de Moebius guarda a relação entre língua e nacionalidades possivelmente ocupadas por judeus - embora o texto não ofereça isso como regra -, o que põe na ordem do dia novamente o par localização-deslocamento, mas direcionando-o a outro campo. $\mathrm{Na}$ verdade, o corpo marca a origem do fundamento que foi reproduzido também para o mapa e para a geografia do hotel. Desse modo, como primeira geografia, a anatomia humana é paradigma que ecoa nas outras formas de representação do espaço. Sabe-se que judeus foram levados a migrar a diversos países para manutenção da própria sobrevivência. O que é ensaiado nas costas de Moebius vai além da demarcação de seus pares, em vista do reconhecimento deles por meio de qualquer língua escrita no corpo. O primeiro campo de atuação de deslocamentos foi o da linguagem. Nesse sentido, tem-se nas costas de Moebius uma imagem de uma disseminação babélica dos corpos-tumba. Os sobreviventes, obedecendo ao deslocamento, oferecem-se enquanto novos locais de memória. E nos países em que não há a presença deles, há a possibilidade de leitura das mortes, traduzidas pela palavra "judeu". A cartografia das línguas feita por Moebius inclina a interpretação para o pensamento de que, associado ao campo linguístico, ele prevê a tradução como modelo de difusão da mensagem. Muito embora a palavra "judeu" tenha um significado religioso, no contexto do romance, o campo semântico que a abarca diz respeito àquilo que foi alvo do projeto genocida e de suas repercussões. Isso quer dizer que ela foi ressignificada pela catástrofe. É essa ressignificação que o romance evidencia na atitude perversa de Moebius sobre si: é necessário legar a todas as línguas possíveis uma nova entrada para o significante no dicionário, agora preenchido com o significado da destruição. 


\section{5 É necessário proteger-se do fim...}

Marc Nichanian assinala que a lei do arquivo "[...] possibilita a vontade genocidiária. Em seguida, é ela que preside à compulsão testemunhal. Mas também é ela, essa mesma lei do arquivo, que traça a linha entre a arte e a história, entre a literatura e o documento: duplo impasse da escrita da violência submetida ao reino do arquivo. [...]” (2012, p. 33). Nesse sentido, essa lei possui uma ambiguidade: todo instrumento de controle, inclusive a máquina genocidiária, carrega em si uma potência produtora de arquivos, a julgar pela quantidade de registros em períodos de forte vigia e opressão. Em se tratando do romance de Gonçalo M. Tavares, verifica-se como a Literatura responde à divisão estipulada por essa lei e a essa produção. Considerando, ainda, como explicita Nichanian, que não há representação possível da Catástrofe, a Literatura, ao apontar 1) as formas de simbolização de Moebius; e 2) o funcionamento da máquina arquivante; inclina o leitor não para a pretenciosa intenção de abraçar a catástrofe, mas direciona-o para a estrutura estruturante de um poder capaz elidir a existência de um grupo. Resta aos que resistem ao engessamento arquivante, isto é, a uma técnica que colaborou com uma das maiores barbáries do século XX, o que o livro apresenta pelo seu teor testemunbal (SELIGMANNSILVA, 2003).

Para Seligmann-Silva,

[a]quele que testemunha sobreviveu - de modo incompreensível - à morte: ele como que a penetrou. Se o indizível está na base da língua, o sobrevivente é aquele que reencena a criação da língua. Nele a morte - o indizível por excelência, que a toda hora tentamos dizer - recebe novamente o cetro e o império sobre a linguagem. O simbólico e o real são recriados na sua relação de mútua fertilização e exclusão. (2003, p. 52)

$\mathrm{O}$ ato de penetração na morte presenciado no texto de Franz Kafka projeta-se ao romance de Gonçalo M. Tavares pela apresentação da imagem das marcas nas costas. O indizível do texto de Kafka está inicialmente na necessidade de aplicação da barbárie como lei, pois tal aplicabilidade lança o leitor para o campo da morte, na qual se acredita por meio da nova exposição em ato. Nota-se que a descrição da máquina, para o oficial, não seria suficiente. Ele julga necessário apresentar sadicamente in loco todo o mecanismo que move 
o sistema jurídico, tendo em vista a posse dos recursos de que dispõe para mostrar a penalidade com aparatos materiais suficientes. O objetivo do oficial é que o evento seja testemunhado em sua autenticidade e, em consequência, exposto em seus pormenores no futuro. Isso quer dizer que ao explorador caberá a responsabilidade a ele transferida: reencenar a criação da língua, transformando simbolicamente o real para que ele seja aceito pelos futuros ouvintes. Para Moebius, a recriação de que fala Seligmann-Silva se realiza de outra forma: inscrevendo-a na própria pele, ele subverte a operação da máquina arquivante para extrair dela a ambígua potência de fazer lembrar $\boldsymbol{e}$ esquecer, ou seja, aquela que tem a capacidade de fazer perpetuar a memória também pode encaminhar a morte ao esquecimento total, expondo a ironia encontrada em sua realização primeira.

Tanto no primeiro caso quanto no segundo, observa-se que os textos literários apresentam fenômenos que inclinam o leitor para a mesma direção:

[...] [a] leitura estética do passado é necessária, pois opõe-se à "musealização" do ocorrido: ela está vinculada a uma modalidade da memória que quer manter o passado vivo no presente. Ao invés da tradicional representação, o seu registro é o índice: ela quer apresentar, expor o passado, seus fragmentos, ruínas e cicatrizes. Não só na literatura, também nas artes plásticas percebe-se percurso em direção ao testemunho, ao trabalho com a memória das catástrofes [...]. As fronteiras entre a estética e a ética tornam-se mais fluidas: testemunha-se o despertar para a realidade da morte. (SELIGMANN-SILVA, 2003, p. 57-58)

O real passa por um processo de estetização. O resultado dessa operação estética traz à baila os problemas de certa narrativa histórica que afasta a memória e o testemunho de seu campo de atuação. O que se verifica nos textos de Kafka e Tavares é uma necessidade: as personagens procuram proteger-se da finalidade de transformação do passado em uma peça histórica a ser contemplada em locais específicos, em razão do mito de que apenas o que está coberto por essas ferramentas seja considerado como verdade (a palavra do explorador e o poder da escrita). A elas cabe a exposição que mantém a memória viva. Em Kafka, a ferida/a cicatriz é a escrita pela qual será lida aquela cultura. Desdobrando intertextualmente tal caso sobre Moebius, em Tavares, as tatuagens serão os fragmentos que reportam a duas vontades: a genocidiária e a de sobrevivência, agora acopladas. É por este viés que se aqui se lê no texto de Gonçalo M. Tavares o teor testemunhal da literatura de que fala Seligmann-Silva também como uma prática de exercício 
ético de alteridade, capaz de despertar o leitor para a morte daqueles que são apresentados no texto literário (e fora dele) como figuras à margem e, devido a essa condição, sequer são lidos como humanos. Isso significa que o trabalho com a memória é - na esteira de Hélène Piralian - uma forma de salvar a morte, a qual, pela escrita literária, também se desloca para a ordem do dia.

Ao fim deste percurso, as costas de Moebius eram para Marius "[...] como um mapa, uma superfície plana; quase dando a sensação de ser uma superfície de duas dimensões, superfície de escrita como uma folha"; para Moebius, eram "[...] uma dimensão quase mítica [,] [...] escudo que o protegia, que o tornava, sentia ele, invulnerável" (TAVARES, 2015, p. 138). Marius lê as costas de Moebius quase como quem lê um depoimento escrito, isto é, como aquilo que passou pela norma do arquivamento e que apenas ganha autonomia após essa etapa. Logo, sua leitura pressupõe um arquivo que confere a possibilidade de legibilidade, assim como também recobra o processo de separação da testemunha do que é testemunhado; do literário e do documental, por consequência. Já Moebius lê com outras lentes: ele o faz pela ponte que precisa estabelecer com seu ouvinte em nome de sua sobrevivência. Destarte, o testemunho por ele elaborado de forma subversiva é o pharmakon que o alimenta e proporciona, mesmo que a custo da dor, a propagação da vida.

\section{Referências:}

ASSMANN, Aleida. Espaços da recordação: formas e transformações da memória cultural. Campinas: Unicamp, 2011.

DERRIDA, Jacques. Mal de arquivo: uma impressão freudiana. Rio de Janeiro: Relume Dumará, 2001.

DIDI-HUBERMAN, Georges. Images malgré tout. Paris: Les Éditions de Minuit, 2003.

FOUCAULT, Michel. Vigiar e punir: nascimento da prisão. Trad. de Raquel Ramalhete. 29. ed. Petrópolis: Editora Vozes, 2004.

KAFKA, Franz. O veredicto / Na colônia penal. Trad. de Modesto Carone. São Paulo: Companhia das Letras, 2011.

NICHANIAN, Marc. "A morte da testemunha. Para uma poética do 'resto' (reliquat)". In: SELIGMANN-SILVA, Márcio; GINZBURG, Jaime; HARDMAN, Francisco Foot (Orgs.). Escritas da violência. Vol. 1: o testemunho. Rio de Janeiro: 7Letras, 2012. 
SELIGMANN-SILVA, Márcio. "Narrar o trauma - a questão dos testemunhos na era de catástrofes históricas”. Psicologia Clínica, no 20, Rio de Janeiro, vol. 1, pp. 65-82, 2008.

"Apresentação da questão: a literatura do trauma". SELIGMANN-SILVA, Márcio. (Org.). História, memória, literatura: o testemunho na era das catástrofes. Campinas, Editora da UNICAMP, 2003.

PIRALIAN, Hélène. Genocidio y transmissión. Trad. de Horacio Pons. Buenos Aires: Fondo de Cultura Económica, 2000.

RICCEUR, Paul. A história, a memória, o esquecimento. Trad. Alain François. Campinas: Unicamp, 2007.

TAVARES, Gonçalo M. Uma menina está perdida no seu século à procura do pai. São Paulo: Companhia das Letras, 2015. 